\title{
Added Value Analysis of Intermediate and Final Cocoa Products: Case Study in a Cocoa Producing Unit in Jember, East Java
}

\author{
Diany Faila Sophia Hartatri ${ }^{1^{*}}$, Alvin Rizki Ramadhani ${ }^{11}$, Sholahuddin Akbar ${ }^{1)}$ \\ Burhanuddin Fauzi $^{1)}$, and Hendy Firmanto ${ }^{1)}$ \\ ${ }^{1}$ Indonesian Coffee and Cocoa Research Institute, J1. PB. Sudirman 90, Jember, Indonesia \\ ${ }^{*}$ Corresponding author: il three@yahoo.com \\ Received: 30 June 2021 / Accepted: 27 July 2021
}

\begin{abstract}
Cocoa is one of the important commodities that significantly contribute to Indonesian economy. Moreover, millions farmers depend on this commodity as their main source of income. However, the low quality of dried cocoa beans produced by Indonesian smallholder cocoa farmers has led the low farm-gate price. Therefore, efforts for increasing the cocoa income are required. Hilirisasi (down streaming) program has been implemented by the Government of Indonesia (Gol), including in cocoa commodity in order to increase the added value of cocoa. There are various downstream products, including intermediate and final products that can be produced. The intermediate products include paste/liquor, cocoa butter, and cocoa powder, meanwhile the final products, such as 3 in 1 cocoa powder, milk chocolate bars and dark chocolate bars. Research on added value of intermediate and final cocoa products especially in small size producing units is still limited, whereas this research is required to support the national economy and smallholder cocoa farmers. Therefore, this research aims to understand the added value of producing intermediate and final cocoa products at a small sized enterprise of cocoa processing unit based in Jember, East Java. This research was conducted in March to June 2020 by conducting observation, documentation and interview for understanding the production activities of intermediate products (cocoa paste/ liquor, cocoa butter and cocoa powder) and final products ( 3 in 1 milk powder, milk chocolate bar and dark chocolate bar). The research results show that producing intermediate and final products resulted in medium to high added value and profitable for the producing unit. Producing cocoa paste/liquor generated the highest profit among the intermediate cocoa products, meanwhile on final cocoa products, processing 3 in 1 cocoa powder provided the highest profit. In order to increase the national and community economy, the support of GoI to small and medium enterprises (SMEs) or farmer groups for processing the downstream cocoa products is required.
\end{abstract}

Keywords: cocoa, added value, downstream, intermediate, final products 


\section{INTRODUCTION}

Cocoa is the key ingredient for chocolate product. Cocoa is one of the estate commodities produced by Indonesia. In 2020, Indonesia is the sixth biggest world cocoa production country, after Cote d'Ivoire, Ghana, Ecuador, Cameroon, and Nigeria with total cocoa production is 200 thousand tonnes (ICCO, 2020). This commodity plays significant role for Indonesian economy because the majority of cocoa products is for export market. In addition, cocoa is also important to support 1,706,663 household farmers' income across Indonesia (Directorate General of Estate Plantation, 2019). Unfortunately, Indonesian cocoa farmers have limitation on accessing working capital for buying agricultural inputs, such as fertilizers, pesticides and labour. Furthermore, the smallholder farmers also find difficulties in accessing extension services provided by government, NGOs and private sector. Further, this has impacted on low productivity and low quality of cocoa beans.

Nowadays, the cocoa productivity is remain about $30 \%$ of its potential production. According to DGEC (2019), the average cocoa productivity was $596.47 \mathrm{~kg} \cdot \mathrm{ha}^{-1}$.year ${ }^{-1}$. This number is lower than that of the potential cocoa production that can reach 2 ton per hectare per year. In addition, the limitation on market information has led farmers to produce unfermented dried cocoa beans marketed to village collectors. Therefore, this has impacted on the low farmer shares of the retail price of cocoa products. Even, Gilbert (2006) states that the producer shares of retail price of cocoa decreased dramatically. This is caused by the power of monopoly and monopsony in the processing industry, which majority conducted by developed countries.

Increasing the price and profit of cocoa beans can be conducted through several approaches, such as intensification and producing downstream products, including intermediate and finish products. The government of Indonesia (GoI) has implemented an export tax policy since 2010 aiming for increasing national income through export on intermediate and final cocoa products. In addition, the imposing of export tax is to increase the added value in domestic cocoa industry (Yudyanto \& Fithra, 2019). Further, according to Bouet \& Laborde (2012), this will decrease the export volume of raw materials which has impacted on the increasing number of cocoa industries in Indonesia. In addition, this has also significantly impacted on Indonesian cocoa export, in which recently the majority of Indonesian cocoa is exported in intermediate products (Yudyanto \& Fithra, 2019). According to ICCO (2020), Indonesia's gross export of cocoa semi-finished products, such as cocoa butter, cocoa powder and cake, and cocoa paste, accounted for 187,130 tonnes, 177,121 tonnes, and 18,357 tonnes, respectively. Further, this has increased the economy benefit obtained by Indonesia.

Furthermore, the GoI has also implemented downstream policy for increasing the added value of several agricultural products, including cocoa. The implementation of downstream policy on cocoa has expanded the opportunity for cocoa producers, including small and medium sized businesses to enable the cocoa producers to increase their income through value added processing by processing intermediated and finished cocoa products. One of the small and medium sized enterprises (SMEs), which focuses on producing cocoa is Sekar that located in Jember, East Java. This production unit produces various cocoa products, both intermediate and finish products. The intermediate products that has been produced by Sekar are cocoa liquor, cocoa butter and cocoa powder. Meanwhile, several finish products producing by Sekar are 3 in 1 cocoa powder, milk and dark chocolate bars, and white chocolate. These products are well received by consumers in the local market 
and prospected to be developed. This research was conducted in order to understand the added value, particularly in the SMEs level of several intermediate products, i.e. cocoa liquor, cocoa butter and cocoa powder and finish cocoa products which are produced by Sekar, namely 3 in 1 cocoa powder, milk chocolate bars and dark chocolate bars.

\section{MATERIALS AND METHODS}

The research was conducted by quantitative method. The data has been collected by observation, documenting and interview with the head of production unit and production staffs to understand the processing of intermediate, i.e. cocoa paste/liquor, cocoa butter and cocoa powder and final cocoa products i.e. 3 in 1 milk powder, milk chocolate bar and dark chocolate bar. The data was collected by recording all of the activities. The collected data were including the variable production costs, such as quantity and price of main materials, labour cost of each process and electricity cost, also fixed production cost of each products, including depreciation cost of machines and factory, factory worker salary, for example head of production unit, production staffs and marketing staffs, and tax. Furthermore, the output of each process of cocoa production was also recorded. Observation, documenting and interview were conducted during MarchJune 2020. This research focused on the case of small and medium sized enterprises (SMEs) cocoa industry unit located in Jember, East Java, Indonesia.

The analysis of added value of cocoa production applying Hayami method. The format of added value analysis (IDR. $\mathrm{kg}^{-1}$ ) is as shows in Table 1. This method has been applied in calculating added value of various commodities, such as coffee (Priantara et al., 2016), seaweed (Ngamel, 2012), downstream product of seaweed at SMEs level (Ngamel, 2015), sweet-star fruit (Maulidah \& Kusumawardani, 2011), and corn chips (Rahman, 2015).

Table 1. Calculating added value by using Hayami method

\begin{tabular}{|c|c|}
\hline Variable & Notes \\
\hline $\begin{array}{l}\text { I. Output, input and price } \\
\text { 1. Output/total product (kg per production process) } \\
\text { 2. Input raw material (kg per production process) } \\
\text { 3. Input labour (HOK per production process) } \\
\text { 4. Conversion factor (kg output per kg raw material) } \\
\text { 5. Labour coefficient (HOK per kg raw material) } \\
\text { 6. Output price } \\
\text { 7. Average labour wage (IDR per production process) }\end{array}$ & $\begin{array}{l}\mathrm{A} \\
\mathrm{B} \\
\mathrm{C} \\
\mathrm{D}=\mathrm{A} / \mathrm{B} \\
\mathrm{E}=\mathrm{C} / \mathrm{B} \\
\mathrm{F} \\
\mathrm{G}\end{array}$ \\
\hline $\begin{array}{l}\text { II. Income and profit } \\
\text { 8. Input raw material price (IDR. } \mathrm{kg}^{-1} \text { ) } \\
\text { 9. Contribution other input (IDR. } \mathrm{kg}^{-1} \text { ) } \\
\left.\text { 10. Output value (IDR. } \mathrm{kg}^{-1}\right) \\
\left.\text { 11. Added value (IDR. } \mathrm{kg}^{-1}\right) \\
\text { • Added value ratio }(\%) \\
\left.\text { 12. Labour income (IDR. } \mathrm{kg}^{-1}\right) \\
\text { - Labour ratio (\%) } \\
\left.\text { 13. Profit (IDR. } \mathrm{kg}^{-1}\right) \\
\text { - Margin }(\%)\end{array}$ & $\begin{array}{l}\mathrm{H} \\
\mathrm{I} \\
\mathrm{J}=\mathrm{D} \times \mathrm{F} \\
\mathrm{K}=\mathrm{J}-\mathrm{H}-\mathrm{I} \\
\mathrm{L}=\mathrm{K} / \mathrm{J} \times 100 \% \\
\mathrm{M}=\mathrm{E} \times \mathrm{G} \\
\mathrm{N}=\mathrm{M} / \mathrm{K} \times 100 \% \\
\mathrm{O}=\mathrm{K}-\mathrm{M} \\
\mathrm{P}=\mathrm{O} / \mathrm{J} \times 100 \%\end{array}$ \\
\hline $\begin{array}{l}\text { III. Remuneration for production factors } \\
\text { 14. Margin (IDR. } \mathrm{kg}^{-1} \text { ) } \\
\text { • Income labour }(\%) \\
\text { • Contribution other input (\%) } \\
\text { Profit }(\%)\end{array}$ & $\begin{array}{l}\mathrm{Q}=\mathrm{J}-\mathrm{H} \\
\mathrm{R}=\mathrm{M} / \mathrm{Q} \times 100 \% \\
\mathrm{~S}=\mathrm{I} / \mathrm{Q} \times 100 \% \\
\mathrm{~T}=\mathrm{O} / \mathrm{Q} \times 100 \%\end{array}$ \\
\hline
\end{tabular}




\section{RESULTS AND DISCUSSION}

Indonesia faces cocoa trading issues, including low quality of cocoa beans produced by smallholder farmers and complex value chain (Neilson, 2007). The majority of smallholder cocoa farmers produce dried unfermented cocoa beans and encash the dried cocoa beans to village collector. Further, this has impacted on low price at smallholder farmers' level and low smallholder farmers' income. Moreover, the fluctuations of the price of cocoa beans have worsened the condition of Indonesian smallholder cocoa farmers. Therefore, increasing the smallholder farmers' living income is required for lifting smallholder farmers out of poverty (Waarts et al., 2019).

There are several options on the effort to increase the income gained from cocoa in the farmers' level. Mainly, the current efforts focus on technical solutions, such as increasing productivity and diversifying production. However, increasing the productivity will be influenced on various factors, such as age of farmers, education level of smallholder farmers and family size of household farmers (Amos, 2007), gender, access to extension services, access to credit, and shade level (Binam et al., 2008), land size, agricultural inputs (fertilizers, labour), farm implements and living capital (Othman, 1990). Therefore, there are various factors influencing the efforts on increasing cocoa productivity.

Diversifying production can be conducted through producing primary by-products of cocoa, intermediate products and finished products (Sukha, 2003). The main by-products of cocoa are including cocoa pod husks, mucilage, cocoa bean shells, and cocoa meal (fragments of cocoa bean). The main by-products of cocoa is commonly used as poultry and animal feed taking from the pod husks (Puastuti \& Susana (2014), Sukardi et al. (2012), Umela (2016), Karda et al. (2015),
Suparjo et al. (2011)), cocoa bean shells and cocoa meal. In addition, there are other products that can be produced by using pod husks, such as the source of potassium carbonate to produce soap (Sukha, 2003), the medium for producing raw materials of bioplastics (Rambat et al. (2015)), as catalyst heterogenic on the production of bioenergy (Tarigan, 2017), fertilizers and mulch. Therefore, the by-products of cocoa is beneficial for increasing the smallholder cocoa farmers' income or increasing the performance of cocoa plants in the field.

The intermediate cocoa products are such as cocoa paste, cocoa butter, and cocoa powder. Producing these products requires several machines, such as roaster, desheller, grinder, cocoa pressing machine, cocoa powder crusher machine, and cocoa powder sieving machine. These products are raw material of various final products. Meanwhile, the finish products are very diverse. Nowadays the usage of cocoa in an increasingly diverse variety of products, not only as a raw material for food products, but also as the raw material for the production of additional nutrition and cosmetics products. According to Kim et al. (2011), cocoa bean contains phytochemicals in high concentration, such as monomeric and oligomeric flavanols. These phytochemicals are beneficial for human health, such as cardiovascular diseases and diabetes, increases the cerebral blood flow that suggested for dementia treatment, preventing cancer, and inhibiting tumor growth. In addition, cocoa improves skin texture and appearance, has moisturizing skin, and protecting from UV light.

The production process of intermediate and final cocoa products is started from processing dried cocoa beans. In Indonesia and other cocoa producing countries, the dried cocoa beans is majority produced by smallholder farmers. As mentioned above, since 2010, the export volume of Indonesian 
dried cocoa beans is decreasing, meanwhile the export volume of processed cocoa products is increasing. Further, the dried cocoa beans and cocoa semi-finished products is exported to traditional exporting countries, including the USA, Malaysia, India, Europe, and others. Therefore, the increasing added value of cocoa by producing intermediate and finish products in producing countries, including Indonesia is still debated. However, according to Sukha (2003), the production of cocoa, including the by-products into various products will increase rural economy and providing employment in rural area.

In order to produce high quality of cocoa products, the fermentation cocoa beans is required. This is because the fermentation process is one of the important processes that impacted on taste, flavour (Dina et al., 2015; Kongor et al., 2016) and characteristics of cocoa (Gu et al., 2013). However, the majority of Indonesian cocoa is produced by traditional method, without fermentation process (Apriyanto et al., 2016; Gu et al., 2013) as fermentation process is considered costly and financial unviable. Furthermore, this is also caused by the limited access of farmers to extension services provided by cocoa stakeholders and limited processing facilitates in the farmers' level. According to Neilson (2007), Regional Estate Crops offices (Dinas Perkebunan, or Disbun, under the Directorate General of Estate Crops) have rarely providing effective extension services to smallholder cocoa farmers. Exacerbated, the regional autonomy that has been started in 1999 has worsen this condition because this has increased the uncertainty of the role and function of extension services in Indonesia. In addition, the smallholder farmers require a fast turnover money to meet the daily needs of household farmer. Therefore, the quality of dried cocoa beans produced by Indonesian smallholder farmers has a tendency to be low and vary.
Since the Cocoa of Excellence (CoE) and International Cocoa Awards (ICA) were launched in 2008, the awareness of cocoa producing countries to produce the high quality of cocoa is increasing. This program has also increased the opportunity to establish relationships between producers and specialty cocoa producers or manufacturers (Eskes et al., 2012). In Indonesia, this has increased the motivation of Indonesian smallholder farmers on producing fermented cocoa beans. In the market, there is price difference between fermented and unfermented cocoa beans, amounted from IDR 3.000 to IDR $10.000 . \mathrm{kg}^{-1}$, depends on the quality and other factors. Therefore, producing fermented cocoa beans has impacted on higher farm gate price in the smallholder cocoa farmers' level. The fermented cocoa beans product contributes to the chocolate industry, both micro, small and medium scale and large cocoa manufacturers. According to BPS (2020), in 2019, there are 1,642,662 and 43,258 of small and medium enterprises (SMEs) scale of food and existing beverages industry, respectively.

The small scale of cocoa industry under study has succeeded in producing and marketing various cocoa products, particularly in the local market. The various cocoa products produced by processingunit are both intermediate and final products. In order to obtain a high quality of downstream products, The processingunit is using fermented dried cocoa beans. The appropriate steps of dried bean process is including a) sorting the cocoa pods from pest and disease infected pods, b) breaking the pods with blunt object such as wood, c) sorting the health cocoa beans from infected cocoa beans, d) putting the cocoa beans into a fermentation box for 4 5 days and cover it with banana leaves or other material, such as plastic, or jute sack, e) turning the cocoa beans every 2 days, and f) drying the cocoa beans by applying sun 
drying or solar drying until the water content of cocoa is about $7 \%$. The quality control plays important role in maintaining the quality and will influence on the quality of end products.

\section{Added Value of Intermediate Products}

The Government of Indonesia (GoI) has established a policy known as industrial 'hilirisasi' aimed to accelerate economic growth, support the industrial base of the economy, added value for export and domestic products, develop the spatial distribution of industry across Indonesia, substitutes imports, and increase employment (KEMENPERIN, 2016). Throughout this policy, the Ministry of Agriculture is promoting off farm activities for increasing the value, farmers' income and improving welfare of Indonesian community. Since this policy was established, in 2016 there were about 33 cocoa processing and downstream industry (cocoa grinding and chocolate manufacturing companies) operating in Indonesia (Dwiartama et al., 2018).

In this research, the calculating of added value of intermediate cocoa products conducted based on three various products, such as cocoa paste/liquor, cocoa butter and cocoa powder. The calculating of the added value of intermediate cocoa products, i.e. cocoa paste, butter and cocoa powder was based on the buying dried fermented cocoa beans price IDR $35,000 . \mathrm{kg}^{-1}$, which the cocoa volume per batch was $100 \mathrm{~kg}$ dried cocoa beans. Meanwhile, the selling prices of cocoa paste, cocoa butter and cocoa powder were IDR $110,000 . \mathrm{kg}^{-1} ; 193,000 . \mathrm{kg}^{-1}$; and $121,000 . \mathrm{kg}^{-1}$, respectively.

The process of cocoa paste is including steaming, roasting, deshelling and grinding of cocoa nib into cocoa paste. Thus, the machinery required in the production of cocoa paste is steamer, roaster, desheller and grinder machine. The additional cost is including electricity and packing cost. Meanwhile, processing cocoa butter is including steaming, roasting, deshelling, grinding into cocoa paste and pressing the cocoa paste that will produce cocoa butter and cocoa cake. Further, the processing of cocoa powder is crushing the cocoa cake, sifting and packaging the cocoa powder. This has led the increasing of labor production cost. The research results show that the labor production cost of cocoa paste, cocoa butter and cocoa powder was IDR 133,854 ; IDR 160,104; and IDR 259,618, respectively.

The simplest processing of cocoa paste has resulted the highest output value, added value, profit and margin compared to cocoa butter and cocoa powder. The results show that the output value of cocoa liquor, cocoa butter and cocoa powder were IDR 90,200; IDR 47,478; and IDR 69,454 respectively. These output values were obtained from the conversion of selling price. Added value is the difference between the value of the product and the accumulated costs of inputs (raw materials) and the contribution of other inputs. The added value ratio of processing $100 \mathrm{~kg}$ dried cocoa beans with buying price of raw materials IDR $35,000 . \mathrm{kg}^{-1}$ became cocoa paste was the highest compared to cocoa butter and cocoa powder accounted for $61.11 \%, 24.94 \%$, and $48.43 \%$, respectively.

In terms of profit, processing cocoa paste has also gained highest profit, i.e. IDR $51,540 . \mathrm{kg}^{-1}$ than that of the cocoa butter and cocoa powder, i.e. IDR $4,752 . \mathrm{kg}^{-1}$ and IDR $18,793 . \mathrm{kg}^{-1}$, respectively. The margin of further process of cocoa beans into cocoa paste, cocoa butter and cocoa powder were IDR $55,200 \cdot \mathrm{kg}^{-1}$, IDR $12,478 . \mathrm{kg}^{-1}$ and $34,454 . \mathrm{kg}^{-1}$ respectively. The percentage of profit received from producing cocoa paste was $93.37 \%$ and the percentage of profit received from further process into produced cocoa butter and cocoa powder was 38.08 and $54.54 \%$ respectively. This mainly because the further 
process of cocoa butter and cocoa powder required higher labour cost and other input cost, such as electricity compared to process of cocoa paste. In addition, the processing cocoa butter has resulted the lowest output value, added value, profit and margin. This is because eventhough the price of cocoa butter is the highest, however the output of cocoa butter processing only produces 24.6 $\mathrm{kg}$ cocoa butter. In order to increase the profit of cocoa butter required the higher selling price. According to the observation in online market, such as Tokopedia the price of cocoa butter marketed by Sekar is the lowest. For example, the price of unrefined cocoa butter produced by one of the cocoa industries in Bandung is IDR 288.000. $\mathrm{kg}^{-1}$. Therefore, increasing the price of cocoa butter produced by Sekar could be recommended for increasing the profit.

\section{Added Value of Final Products}

Recently, the diversification products of cocoa increased significantly. Cocoa is not only used for producing food products but also used for producing other products, such as cosmetics and pharmaceutical. However, this research only analyse three (3) various products, i.e. 3 in 1 milk powder, milk chocolate bar and dark chocolate bar as these products are the best seller products of Sekar. The machineries that are required for processing 3 in 1 cocoa powder and chocolate bars are including: a) steamer, b) roaster, c) desheller, e) cocoa grinder , f) pressing machine, g) cocoa cake breaking machine, h) blending machine, i) conching machine , j) moulding, $\mathrm{k}$ ) tempering racks, and l) air conditioning.

Several steps of cocoa powder production is including these steps: 1) cocoa grinding (kibbling), 2) refining, 3) sieving, and 4) packaging. In general, the production of 3 in 1 cocoa powder is similar with the production of cocoa powder. However, there is a blending step in the processing of 3 in 1 cocoa powder, as there are additional material, i.e. milk and sugar. Meanwhile, the production of milk and dark chocolate bars is generally similar, the difference lies only in the formula for the mixture of auxiliary ingredients. Basically, the milk bar chocolate applying more milk and sugar. According to the interview, the demand of this products in the local market is higher than that of the dark chocolate. Nevertheless, the demand of the dark chocolate is believed to continue to increasing along with the increase in the healthy lifestyle in society.

The results (Table 3 ) show that producing 3 in 1 milk powder provided the highest output value, added value, profit and margin. The results show that the output value of 3 in 1 milk powder, milk chocolate bar and dark chocolate bar was IDR 338,839; IDR 263,654; and IDR 321,077 respectively. The added value of 3 in 1 milk powder was the highest, i.e. IDR $272,472 . \mathrm{kg}^{-1}$ compared to the added value of milk chocolate bar and dark chocolate bar, accounted for IDR $115,894 . \mathrm{kg}^{-1}$ and IDR $216,533 . \mathrm{kg}^{-1}$ respectively. The added value ratio of 3 in 1 milk powder, milk chocolate bar and dark chocolate bar was $80.41 \%$, $43.96 \%$ and $67.44 \%$, respectively.

According to the Table 2, in terms of the profit, processing 3 in 1 milk powder gained the highest profit than that of the dark chocolate bar and milk chocolate bar. The profit of 3 in 1 milk powder was IDR $198,230 . \mathrm{kg}^{-1}$, meanwhile the profit of dark chocolate bar and milk chocolate bar was IDR 131,408. $\mathrm{kg}^{-1}$ and IDR 49,488. $\mathrm{kg}^{-1}$ respectively. The profit margin of processing 3 in 1 milk powder was the highest, i.e $65.24 \%$, while the profit margins of processing milk chocolate bar and dark chocolate bar were $21.64 \%$ and $45.93 \%$, respectively.

According to the research the processing 3 in 1 milk powder requires seven days. 
Table 2. Calculating added value of intermediate cocoa products using Hayami method

\begin{tabular}{|c|c|c|c|c|}
\hline Cocoa & Notes & Paste & Cocoa Butter & Cocoa powder \\
\hline \multicolumn{5}{|l|}{ I. Output, input and price } \\
\hline 1. Output/total product (kg per production process) & A & 82 & 24.6 & 57.4 \\
\hline 2. Input raw material (kg per production process) & B & 100 & 100 & 100 \\
\hline 3. Input labour (HOKper production process) & $\mathrm{C}$ & 2.68 & 4.43 & 5.72 \\
\hline 4. Conversion factor (kg output per $1 \mathrm{~kg}$ raw material) & ) $\mathrm{D}=\mathrm{A} / \mathrm{B}$ & 0.82 & 0.246 & 0.574 \\
\hline 5. Labour coefficient (HOK per kg raw material) & $\mathrm{E}=\mathrm{C} / \mathrm{B}$ & 0.027 & 0.04 & 0.057 \\
\hline 6. Output price & $\mathrm{F}$ & 110,000 & 193,000 & 121,000 \\
\hline 7. Average labour wage (IDR per production process) & G & 133,854 & 160,104 & 259,618 \\
\hline \multicolumn{5}{|l|}{ II. Income and profit } \\
\hline 8. Input raw material price (IDR. $\mathrm{kg}^{-1}$ ) & $\mathrm{H}$ & 35000 & 35000 & 35000 \\
\hline 9. Contribution other input (IDR. $\mathrm{kg}^{-1}$ ) & I & 76.39 & 638.27 & 817.77 \\
\hline 10. Output value (IDR. $\mathrm{kg}^{-1}$ ) & $\mathrm{J}=\mathrm{D} * \mathrm{~F}$ & 90,200 & 47,478 & 69,454 \\
\hline 11. Added value (IDR. $\mathrm{kg}^{-1}$ ) & $\mathrm{K}=\mathrm{J}-\mathrm{H}-\mathrm{I}$ & 55,124 & 11,840 & 33,636 \\
\hline$\square$ Added value ratio (\%) & $\mathrm{L}=\mathrm{K} / \mathrm{J} * 100 \%$ & 61.11 & 24.94 & 48.43 \\
\hline 12. Labour income (IDR. $\mathrm{kg}^{-1}$ ) & $\mathrm{M}=\mathrm{E}^{*} \mathrm{G}$ & 3,583 & 7,088 & 18,843 \\
\hline$\square \quad$ Labour ratio (\%) & $\mathrm{V}=\mathrm{M} / \mathrm{K} * 100 \%$ & 6.50 & 59.86 & 44.13 \\
\hline 13. Profit (IDR/kg) & $\mathrm{O}=\mathrm{K}-\mathrm{M}$ & 51,540 & 4,752 & 18,793 \\
\hline$\square \operatorname{Margin}(\%)$ & $\mathrm{P}=\mathrm{O} / \mathrm{J} * 100 \%$ & 57.14 & 10.01 & 27.06 \\
\hline \multicolumn{5}{|l|}{ III. Remuneration for production factors } \\
\hline 14. Margin (IDR.kg ${ }^{-1}$ ) & $\mathrm{Q}=\mathrm{J}-\mathrm{H}$ & 55,200 & 12,478 & 34,454 \\
\hline$\square$ Income labour (\%) & $=\mathrm{M} / \mathrm{Q} * 100 \%$ & 6.49 & 56.80 & 43.08 \\
\hline$\square$ Contribution other input (\%) & $\mathrm{S}=\mathrm{I} / \mathrm{Q}^{*} 100 \%$ & 0.14 & 5.12 & 2.37 \\
\hline - Profit $(\%)$ & $=\mathrm{O} / \mathrm{Q} * 100 \%$ & 93.37 & 38.08 & 54.54 \\
\hline
\end{tabular}

Table 3. Calculating added value of end cocoa products using Hayami method

\begin{tabular}{|c|c|c|c|c|}
\hline & Notes & 3 in 1 milk & $\begin{array}{l}\text { Chocolate } \\
\text { milk bar }\end{array}$ & $\begin{array}{c}\text { Chocolate } \\
\text { dark bar }\end{array}$ \\
\hline \multicolumn{5}{|l|}{ I. Output, input and price } \\
\hline 1. Output/total product (kg per production process) & A & 375 & 44.94 & 44.94 \\
\hline 2. Input raw material (kg per production process) & $\mathrm{B}$ & 100 & 53.57 & 41.79 \\
\hline 3. Input labour (HOK per production process) & $\mathrm{C}$ & 13.58 & 10.89 & 10.89 \\
\hline 4. Conversion factor ( $\mathrm{kg}$ output per $1 \mathrm{~kg}$ raw material & al) $\mathrm{D}=\mathrm{A} / \mathrm{B}$ & 3.75 & 0.84 & 1.08 \\
\hline 5. Labour coefficient (HOK per kg raw material) & $\mathrm{E}=\mathrm{C} / \mathrm{B}$ & 0.17 & 0.20 & 0.26 \\
\hline 6. Output price & $\mathrm{F}$ & 90,357 & 314,285 & 298,571 \\
\hline 7. Average labour wage (IDR per production process) & G & 437,490 & 326,663 & 326,663 \\
\hline \multicolumn{5}{|l|}{ II. Income and profit } \\
\hline 8. Input raw material price (IDR. $\mathrm{kg}^{-1}$ ) & $\mathrm{H}$ & 35,000 & 35,000 & 35,000 \\
\hline 9. Contribution other input (IDR. kg ${ }^{-1}$ ) & I & 31,368 & 112,760 & 69,544 \\
\hline 10. Output value (IDR. $\mathrm{kg}^{-1}$ ) & $\mathrm{J}=\mathrm{D} * \mathrm{~F}$ & 338,839 & 263,654 & 321,077 \\
\hline 11. Added value (IDR.kg ${ }^{-1}$ ) & $\mathrm{K}=\mathrm{J}-\mathrm{H}-\mathrm{I}$ & 272,472 & 115,894 & 216,533 \\
\hline$\square$ Added value ratio (\%) & $\mathrm{L}=\mathrm{K} / \mathrm{J} * 100 \%$ & 80.41 & 43.96 & 67.44 \\
\hline 12. Labour income (IDR.kg-1) & $\mathrm{M}=\mathrm{E} * \mathrm{G}$ & 74,242 & 66,405 & 85,125 \\
\hline$\square$ Labour ratio (\%) & $\mathrm{N}=\mathrm{M} / \mathrm{K} * 100 \%$ & 27.25 & 57.30 & 39.31 \\
\hline 13. Profit (IDR. kg ${ }^{-1}$ ) & $\mathrm{O}=\mathrm{K}-\mathrm{M}$ & 198,230 & 49,488 & 131408 \\
\hline$\square$ Margin (\%) & $\mathrm{P}=\mathrm{O} / \mathrm{J} * 100 \%$ & 58.50 & 18.77 & 40.93 \\
\hline \multicolumn{5}{|l|}{ III. Remuneration for production factors } \\
\hline 14.Margin (IDR. $\left.\mathrm{kg}^{-1}\right)$ & $\mathrm{Q}=\mathrm{J}-\mathrm{H}$ & 303,839 & 228,654 & 286,077 \\
\hline$\square$ Income labour (\%) & $\mathrm{R}=\mathrm{M} / \mathrm{Q} * 100 \%$ & 24.43 & 29.04 & 29.76 \\
\hline$\square$ Contribution other input (\%) & $\mathrm{S}=\mathrm{I} / \mathrm{Q}^{*} 100 \%$ & 10.32 & 49.31 & 24.31 \\
\hline - Profit (\%) & $\Gamma=\mathrm{O} / \mathrm{Q}^{*} 100 \%$ & 65.24 & 21.64 & 45.93 \\
\hline
\end{tabular}


Meanwhile, the processing milk and dark chocolate bars require four days. This because processing 3 in 1 milk chocolate is more complex compared to producing chocolate bars. Moreover, this has also led by the small capacity of shifting, blending, sugar refining and cocoa paste pressing machines. Thus, this increased the labour cost. However, processing 3 in 1 cocoa powder requires lowest additional inputs compared to processing chocolate bars. The additional inputs required on producing 3 in 1 milk powder are mainly creamer, sugar and packaging. Meanwhile, the additional inputs required on producing milk and dark chocolate bars are including creamer, sugar, milk powder, cocoa butter, and packaging. Therefore, producing 3 in 1 cocoa powder is more beneficial than that of chocolate bars. The profit margin of dark chocolate bar is higher than that of the milk chocolate bar is mainly caused by the lowest volume of additional inputs. Further, this decreased the additional inputs costs of processing dark chocolate bar.

Increasing the added value of cocoa products into downstream products that are ready to be consumed is believed can increase the income as the higher added value. Table 1 shows that the value added ratio of producing cocoa paste and cocoa powder resulted high added value ratio, however producing cocoa butter resulted medium added value ratio (Reyne cit. Hubeis, 1997). Meanwhile, Table 2 indicates that the added value ratio of processing end products, such as 3 in 1 cocoa powder, milk chocolate bar and dark chocolate bar can be categorized as high value added. Therefore, the further process either intermediate and end products at the small and medium enterprises (SMEs) could be implemented in Indonesia as an effort to increase the competitiveness of Indonesian cocoa industry. Another benefits could be received by conducting further process of raw cocoa beans into intermediate and final products at the SMEs are increasing employment opportunity, increasing community living income and increasing country's foreign exchange earnings from export and strengthening the national industrial structure (Hubeis, 1997). Further, this could increase the national economy (Putri, et al., 2015).

\section{CONCLUSIONS}

Indonesian dried cocoa beans is well known as low quality beans. This has impacted on low income, both at the farmers and national level. Hilirisasi program has been implemented by the Government of Indonesia $(\mathrm{GoI})$ in order to increase the added value of cocoa product, thus this will increase the income of community and national economy derived from cocoa sector. Throughout the program, the GoI encourages the cocoa farmer groups nor micro, small and medium enterprises (MSMEs) to produce intermediate, such as cocoa paste/liquor, cocoa butter and cocoa cake; also end cocoa products, including 3 in 1 cocoa powder, milk chocolate bars and dark chocolate bar. According to the research results, producing intermediate and final products produces a moderate to high added value ratio, however there are several challenges faced by MSMEs and farmer groups in processing downstream products, such as limitation on human resource capacity, financing and facilities, including unit processing and machinery. Therefore, support from GoI is crucial to promote strong and inclusive economic growth. Moreover, during the pandemic Covid-19 support for MSMEs should be increased because MSMEs have high resilience and have high contribution on foreign exchange to national income. 


\section{REFERENCES}

Amos, T.T. (2007). An analysis of productivity and technical efficiency of smallholder cocoa farmers in Nigeria. Journal of Social Sciences, 15(2), 127-133.

Apriyanto, M.; Sutardi; Supriyanto \& H. Eni (2016). Study on effect of fermentation to the quality parameter of cocoa bean in Indonesia. Asian Journal Diary and Food Research, 35(2), 160-163.

Binam, J.N.; J. Gockowski \& G.B. Nkamleu (2008). Technical efficiency and productivity potential of cocoa farmers in West African countries. The Developing Economies, XLVI-3, 242-263.

Bouet, A. \& D. Laborde (2012). Food crisis and export taxation: the cost of non-cooperative trade policies. Review of World Economics, 148(1), 209-233.

Dina, S.F.; H. Ambarita; F.H. Napitupulu \& H. Kawai (2015). Study on effectiveness of continuous solar dryer integrated with desiccant thermal storage for drying cocoa beans. Case Studies in Thermal Engineering, 5, 32-40.

DGEC (2019). Tree Crop Estate Statistics of Indonesia 2018-2020. Directorate General of Estate Crops, Ministry of Agriculture, Jakarta.

Dwiartama, A.; N. Jeffry \& D. Permadi (2018). Hilirisasi: Resource-based Industrialisation and Global Production Networks in the Indonesian Coffee and Cocoa Sectors. ACIAR.

Eskes, B.; A. Sophie; J. Francoise; Ed. Seguine; D. Sukha.; W. Stephen; T. Janis; R. Julien; L. Brigitte; B. Michel; C. Emile; F. Nelly \& H. Kristen (2012). Improving the profitability of small and medium-sized farms: the principal key to a global sustainable cocoa economy. $17^{\text {th }}$ International Cocoa Research Conference. Yaounde, Cameroun.

Gilbert, C. (2006). Value Chain Analysis and Market Power in Commodity Processing with Application to the Cocoa and Coffee Sectors. Department of Economics, University of Trento, Italia. Department of Economics Working Papers.
Gu, F.; L. Tan; H. Wu; Y. Fang; F. Xu; Z. Chu \& Q. Wang (2013). Comparison of cocoa beans from China, Indonesia, and Papua New Guinea. Foods, 2, 183-197.

Hubeis, M. (1997). Towards a Professional Small Industry in the Era of Globalization Through the Empowerment of Industrial Management. Institute Pertanian Bogor.

International Cocoa Organization (ICCO) (2020). Production QBCS-XLVII No.2. https:/ /www.icco.org/wp-content/uploads/ Production_QBCS-XLVII-No.-2.pdf.

Karda, I.W.; Bulkaini; M. Ashari \& Tarmizi (2015). Profil nutrisi kulit buah kakao yang difermentasi dengan fermentor berbeda. Jurnal Ilmu dan Teknologi Peternakan Indonesia, 1(1), 40-46.

KEMENPERIN (2016). Media Industri. Edisi 1. Kementerian Perindustrian Republik Indonesia. Jakarta.

Kim, J.; L. Ki Won \& J.L. Hyoong (2011). Nuts and Seeds in Health and Disease Prevention: Cocoa (Thebroma cacao) Seeds and Phytochemicals in Human Health. Academic Press. Elsevier. P. 351-360.

Kongor, J.E.; H. Michael; V.D.W. Davy; O.A. Emmanuel; B. Pascal \& D. Koen (2016). Factors influencing quality variation in cocoa (Theobroma cacao) bean flavour profile - A Review. Food Research International, 82, 44-52.

Maulidah, S. \& F. Kusumawardani (2011). The added value of sweet star fruit (Averrhoa carambola L.) agroindustry and optimization of output as an effort to increase the income. AGRISE, 11(1), 1412-1425.

Neilson, J. (2007). Global markets, farmers, and the state: Sustaining profits in the Indonesian cocoa sector. Bulletin of Indonesian Economic Studies, 43(2), 227-250.

Ngamel, A.K. (2012). Financial analysis of seaweed cultivation and added value of carrageenan flour in Kei Kecil Sub-District, Southeast Maluku District. Jurnal Sains Terapan, 2(1), 39-47. 
Ngamel, A.K. (2015). Business analysis and added value of processing dodol seaweed in household scale of Loon Village, Kei Kecil Sub-District, Southeast Maluku District. Jurnal Sains Terapan, 5(1), 40-49.

Othman, N. (1990). Factors Affecting Cocoa Productivity Among the Smallholders in West Malaysia. PhD Thesis. University of Stirling. UK.

Priantara, I.D.G.Y.; S. Mulyani \& I.K. Satriawan (2016). Analysis of the added value of processing Arabica coffee Kintamani. Jurnal Rekayasa dan Manajemen Agroindustri, 4(4), 33-42.

Puastuti, W. \& I.W.R. Susana (2014). Potensi dan pemanfaatan kulit buah sebagai pakan ternak alternatif ternak ruminansia. WARTAZOA, 24(3), 15-159.

Putri, A.S.; S. Wahyudi; P. Socia; C.D.P. Ryan (2015). Value chain improvement for cocoa industry in Indonesia by input-output analysis. Proceeding of the International Multi Conference of Engineers and Computer Scientists 2015, Vol II, IMECS 2015, March ,18-20, Hong Kong.

Rahman, S. (2015). Analysis of added value of corn chips agro-industry. Jurnal Aplikasi Teknologi Pangan, 4(3), 108-111.

Rambat; H.A. Nurul \& R. Bambang (2015). Aplikasi limbah kulit buah kakao sebagai media fermentasi asam laktat untuk bahan baku bioplastik. Jurnal Kimia Kemasan, 37(2), 103-110.

Sukardi; H. Senny \& W. Yunita (2012). Penggunaan tepung kulit buah kakao pada pakan pengaruhnya terhadap pertumbuhan dan produksi gurami. Jurnal Perikanan, XIV(2), 57-63.

Sukha, D.A. (2003). Potential value added products from Trinidan and Tobago cocoa. p. 69-73.
In: Proceedings of seminar/exhibition on the revitalisation of the Trinidad and Tobago cocoa industry-Targets, Problems and Options. The Association of Professional Agricultural Scientist of Trinidad and Tobago (APASTT), Faculty of Science and Agriculture, The University of the West Indies, St. Augustine, $20^{\text {th }}$ September 2003.

Suparjo; K.G. Wiryawan; E.B. Laconi \& D. Mangunwidjaja (2011). Performa kambing yang diberi kulit buah kakao terfermentasi. Media Peternakan, 35-41.

Tarigan, T.F.L. (2017). Pemanfaatan Limbah Kulit Buah Kakao (cacao pod husk) menjadi Katalis Heterogen $\mathrm{K}_{2} \mathrm{O}$ pada Pembuatan Biodosel dari Limbah Jelantah: Pengaruh Suhu Kalsinasi. Skripsi. Departemen Teknik Kimia. Fakultas Teknik. Universitas Sumatera Utara. Medan.

Umela, S. (2016). Fermentasi kulit buah kakao (Theobroma cacao) sebagai bahan pakan ternak. Jetch, 4(2). 107-115.

Waarts, Y.; J. Valerie; I. Verina; S. Maja;V.R. Fédes; B. Gonne; D. Just; V.V. Jiska; A. Eric; S. Merieke; G. Joost \& V.V. Simone (2019). A Living Income for Smallholder Commodity Farmers and Protected Forests and Biodiversity: How Can the Private and Public Sectors Contribute?. Wagening Economic Research. White paper on sustainable commodity production.

Yudyanto, H. \& Fithra, F.H. (2019) Analysis of the imposition of export tax on Indonesian cocoa beans: Impact on the processed cocoa export in Indonesia and Malaysia. In: Globalization, Productivity and Production Networks in ASEAN (Hastiadi, F. (Eds)). Palgrave Macmillan, Cham. 